\title{
Selected Readings on Ethnicity, Family, and Community
}

\author{
Compiled by \\ Mary E. Kelly \\ Central Missouri State University \\ and \\ Thomas W. Sanchez \\ University of Nebraska-Lincoln
}

\section{Anthologies and Edited Volumes}

Bammer, Angelika, ed. Displacements: Cultural Identities in Question (Bloomington, IN: Indiana University Press, 1994).

Barresi, Charles M. and Donald Edgar Stull, eds. Ethnic Elderly and Long-term Care (NY: Springer Publishing Co., 1993).

Castile, George Pierre, Gilbert Kushner and William Yewdale Adams, eds. Persistent Peoples: Cultural Enclaves in Perspective (Tucson: University of Arizona Press, 1981).

Dublin, Thomas, ed. Becoming American, Becoming Ethnic: College Students Explore Their Roots (Philadelphia: Temple University Press, 1996).

Faure, David and Helen F. Siu, eds. Down to Earth: The Territorial Bond in South China (Stanford, CA: Stanford University Press, 1995).

Fischer, William C., ed. Identity, Community and Pluralism in American Life (NY: Oxford University Press, 1997).

Goldscheider, Frances K. and Calvin Goldscheider, eds. Ethnicity and the New Family Economy: Living Arrangements and Intergenerational Financial Flows (Boulder, CO: Westview Press, 1989). 
Hood, Jane C., ed. Men, Work and Family (Newbury Park: Sage Publications, 1993).

Jacobson, Cardell K., ed. American Families: Issues in Race and Ethnicity (New York: Garland Press, 1995).

Krausz, Ernest, ed. Studies of Israeli Society (New Brunswick: Transaction Press, 1980).

Levinson, Bradley A., Douglas E. Foley and Dorothy C. Holland, eds. The Cultural Production of the Educated Person: Critical Ethnographies of Schooling and Local Practice (Albany, NY: University of New York Press, 1996).

Lipset, Martin Seymour, ed. American Pluralism in the Jewish Community (New Brunswick, NJ: Transaction Publishers, 1990).

McAdoo, Harriette Pipes, ed. Family Ethnicity: Strength in Diversity (Newbury Park, CA: Sage Publishing, 1993).

McGoldrick, Monica, Joe Giordano and John K. Pearce, eds. Ethnicity and Family Therapy (NY: Guilford Press, 1996).

Mindel, Charles H., Robert Wesley Habenstein and Roosevelt Wright, eds. Ethnic Families in America: Patterns and Variations, 3rd ed. (New York: Elsevier North Holland, 1988).

Moore, Joan W. and Raquel Pinderhughes, eds. In the Barrios: Latinos and the Underclass Debate (New York: Russell Sage Foundation, 1993).

Pearson, Jane L. and Yeates Conwell, eds. Suicide and Aging: International Perspectives (NY: Springer Publishing Company, 1996).

Pozzetta, George E., ed. American Immigration and Ethnicity: The Immigrant Women (New York: Garland Publishing, Inc., 1991).

Pozzetta, George E., ed. Immigrant Family Patterns: Demography, Fertility, Housing, Kinship, and Urban Life (New York: Garland Publishing, Inc., 1991).

Taylor, Ronald L., ed. Minority Families in the United States (Englewood Cliffs, NJ: Prentice Hall, 1994). 
Walch, Timothy, ed. Immigrant America: European Ethnicity in the United States (NY: Garland, 1994).

Watkins, Susan Cotts, ed. After Ellis Island: Newcomers and Natives in the 1910 Census (NY: Russell Sage Foundation, 1994).

Westwood, Sallie and Parminder Bhachu, eds. Enterprising Women: Ethnicity, Economy and Gender Relations (NY: Routledge, 1988).

\section{Books}

Abrahamson, Mark. Urban Enclaves: Identity and Place in America (New York: St. Martin's Press, 1996).

Acock, Alan C. and David H. Demo. Family Diversity and Well-being (Thousand Oaks, CA: Sage Publications, 1994).

Acock, Alan C. The Influence of the Family (New York: Garland, 1986).

Augustinos, Gerasimos. The Greeks of Asia Minor: Confession, Community and Ethnicity in the Nineteenth Century (Kent, $\mathrm{OH}$ : Kent State University Press, 1992).

Almirol, Edwin B. Ethnic Identity and Social Negation: A Study of a Filipino Community in California (New York: AMS Press, 1985).

Benson, James K. Irish and German Families and the Economic Development of Midwestern Cities, 1860-1895 (NY: Garland, 1990).

Blea, Irene J. Researching Chicano Communities: Social, Historical, Physical, Psychological, and Spiritual Space (Westport, CT: Praeger, 1995).

Bousquet, Gisèle L. Behind the Bamboo Hedge: The Impact of Homeland Politics in the Parisian Vietnamese Community (Ann Arbor: University of Michigan Press, 1991).

Di Leonardo, Micaela. The Varieties of Ethnic Experience: Kinship, Class and Gender Among California Italian-Americans (Ithaca, NY: Cornell University, 1984).

Erdmans, Mary Patrice. "Émigrés and Ethnics: Patterns of Cooperation Between New and Established Organizations in Chicago's Polish Community" (Ph.D. diss., Northwestern University, 1992). 
Ethnic Studies Review, Vol. 19, No. 1

Fugita, Stephen and David J. O'Brien. Japanese American Ethnicity: The Persistence of Community (Seattle: University of Washington Press, 1991).

Gerber, Stanford Neil. The Ethnography of a Russian-American Community (NY: AMS Press, 1985).

Godfrey, Brian J. Neighborhoods in Transition: The Making of San Francisco's Ethnic and Nonconformist Communities (Berkeley: University of California Press, 1988).

Griswold Del Castillo, Richard. La Familia: Chicano Families in the Urban Southwest, 1848 to the Present (Notre Dame, IN: University of Notre Dame Press, 1984).

Hawkins, John. Inverse Images: The Meaning of Culture, Ethnicity, and Family in Postcolonial Guatemala (Albuquerque: University of New Mexico Press, 1984).

Kaplan, Marion. The Making of the Jewish Middle Class: Women, Family, and Identity in Imperial Germany (New York: Oxford University Press, 1991).

Krase, Jerome. Self and Community in the City (Lanham, MD: University Press of America, 1982).

Kunkelmen, Gary A. The Religion of Ethnicity: Belief and Belonging in a Greek-American Community (NY: Garland, 1990),

Lipset, Martin Seymour. Jews and the New American Scene (Cambridge, MA: Harvard University Press, 1995).

Menchaca, Martha. The Mexican Outsiders: A Community History of Marginalization and Discrimination in California (Austin, TX: University of Texas Press, 1995).

Morawska, Ewa. For Bread with Butter: The Life-world of East Central Europeans in Johnstown, Pennsylvania, 1890-1940 (New York: Cambridge University Press, 1985).

O'Nell, Theresa DeLeane. Disciplined Hearts: History, Identity, and Depression in an American Indian Community (Berkeley: University of California Press, 1996). 
Peshkin, Alan. The Color of Strangers, The Color of Friends: The Play of Ethnicity in School and Community (Chicago: University of Chicago Press, 1991).

Rubin, Lillian B. Families on the Fault Line: America's Working Class Speaks about the Family, the Economy, Race, and Ethnicity (New York: HarperCollins, 1994).

Sanchez, George J. Becoming Mexican American: Ethnicity, Culture and Identity in Chicano Los Angeles, 1900-1945 (New York: Oxford University Press, 1993).

Silverman, Myrna. Strategies for Social Mobility: Family, Kinship and Ethnicity Within Jewish Families in Pittsburgh (NY: AMS Press, 1989).

Slonim, Maureen. Children, Culture, and Ethnicity: Evaluating and Understanding the Impact (New York: Garland Press, 1991.)

Sorrentino, Anthony. Organizing the Ethnic Community: An Account of the Origin, History, and Development of the Joint Civic Committee of Italian Americans (1952-1995), (New York: Center for Migration Studies, 1995).

Suarez-Orozco, Carola and Marcelo Suarez-Orozco. Transformations: Immigration, Family Life, and Achievement Motivation Among Latino Adolescents. (Stanford, CA: Stanford University Press, 1995).

Valle, Isabel. Fields of Toil: A Migrant Family's Journey (Pullman, WA: Washington State University Press, 1994).

Walko, Mary Ann. Rejecting the Second Generation Hypothesis: Maintaining Estonian Ethnicity in Lakewood, New Jersey (NY: AMS Press, 1989).

Washington, Joseph R. Black-Race Family Binds and White-Ethnic Kinship Ties (Tampa, FL: Department of Religious Studies, University of Southern Florida, 1988).

Weibel-Orlando, Joan. Indian Country, LA: Maintaining Ethnic Community in Complex Society (Urbana: University of Illinois Press, 1991).

Willie, Charles Vert. A New Look at Black Families, Third edition (Dix Hills, NY: General Hall, Inc., 1988).

Yanagisako, Sylvia Junko. Transforming the Past: Tradition and Kinship Among Japanese Americans (Stanford, CA: Stanford University Press, 1985). 
Ethnic Studies Review, Vol. 19, No. 1

Zavella, Patricia. Women's Work and Chicano Families: Cannery Workers of the Santa Clara Valley (Ithaca, NY: Cornell University Press, 1987).

\section{Journal Articles and Book Chapters}

Abraham, Margaret, "Ethnicity, Gender, and Marital Violence: South Asian Women's Organization in the United States," Gender and Society 9, 4 (1995), 450-69.

Aguirre, B. E., Rogelio Saenz and Sean-Shong Hwang, "Remarriage and Intermarriage of Asians in the United States of America," Journal of Comparative Family Studies 26, 2 (1995), 207-16.

Austin, Erica Weintraub and C. Leigh Nelson, "Influences of Ethnicity, Family Communication, and Media on Adolescents' Socialization to U.S. Politics," Journal of Broadcasting and Electronic Media 37, 4 (1993), 419-435.

Baumann, Gerd, "Managing a Polyethnic Milieu: Kinship and Interaction in a London Suburb," Journal of the Royal Anthropological Institute 1, 4 (1995), 725-41.

Bean, Roy and D. Russell Crane, "Marriage and Family Therapy Research with Ethnic Minorities: Current Status," American Journal of Family Therapy 24, 4 (1996), 3-9.

Belcove-Shalin, Janet S., "Separatist Orthodoxy's Attitudes Towards Community," in Walter P. Zenner, ed., Persistence and Flexibility: Anthropological Perspectives on the American Jewish Experience (Albany: State University of New York Press, 1988), 208-222.

Borjas, George J., "Long-run Convergence of Ethnic Skill Differentials: The Children and Grandchildren of the Great Migration," Industrial and Labor Relations Review 47, 4 (1994), 553-573.

Botev, Nikolai, "Where East Meets West: Ethnic Intermarriage in the Former Yugoslavia, 1962-1989," American Sociological Review 59, 3 (1994), 461-80.

Brooks-Gunn, Jeanne, Pamela K. Klebanov and Greg J. Duncan, "Ethnic Differences in Children's Intelligence Test Scores: Role of Economic Deprivation, Home Environment, and Maternal Characteristics," Child Development 67, 2 (1996), 396-409. 
Burton, Lynda, Judith Kasper, Andrew Shore, Kathleen Cagney, Thomas LeVeist, Catherine Cubbin, and Pearl German, "The Structure of Informal Care: Are There Differences by Race?" Gerontologist 35, 6 (1995), 744-53.

Cadaval, Olivia, "Making a Place Home: The Latino Festival," in Stephen Stern and John Allan Cicala, eds., Creative Ethnicity: Symbols and Strategies of Contemporary Ethnic Life (Logan, UT: Utah State University Press, 1991), 204-222.

Cameron, James E. and Richard N. Lalonde, "Self, Ethnicity, and Social Group Memberships in Two Generations of Italian Canadians," Personality and Social Psychology Bulletin 20, 5 (1994), 514-20.

Cantor, Marjorie H., Mark Brennan and Anthony Sainz, "The Importance of Ethnicity in the Social Support Systems of Older New Yorkers: A Longitudinal Perspective (1970-1990)," Journal of Gerontological Social Work 22, 3-4 (1994), 95-129.

Caskey, John P., "Bank Representation in Low-Income and Minority Urban Communities," Urban Affairs Quarterly 29, 4 (1994), 617-39.

Crane, Jonathan, "The Epidemic Theory of Ghettos and Neighborhood Effects on Dropping Out and Teenage Childbearing," American Journal of Sociology 96, 5 (1991), 1226-60.

Denton, Nancy A., "Patterns of Neighborhood Transition in a Multi-Ethnic World: U.S. Metropolitan Areas 1970-1980," Demography 28, 1 (1991), 41-63.

DeSantis, Grace and Richard Benkin, "Ethnicity without Community," Ethnicity 7, 2 (1980), 137-43.

DeSena, Judith N., "Women: The Gatekeepers of Urban Neighborhoods," Journal of Urban Affairs 16, 3 (1994), 271-84.

Di Leonardo, Micaela, "The Female World of Cards and Holidays," Signs: Journal of Women in Culture and Society 12, 3 (1987), 440-53.

Erdmans, Mary Patrice, "Immigrants and Ethnics: Conflict and Identity in Chicago Polonia," Sociological Quarterly 36, 1 (1995), 175-95.

Espititu, Yen Le, "Colonial Oppression, Labour Importation, and Group Formation: Filipinos in the United States," Ethnic and Racial Studies 19, 1 (1996), 29-49. 
Fine, Mark A., "Current Approaches to Understanding Family Diversity," Family Relations 42, 3 (1993), 235-8.

Fong, Eric, "Residential Proximity Among Racial Groups in U.S. and Canadian Neighborhoods," Urban Affairs Quarterly 30, 2 (1994), 285-297.

Frankel, Barbara, "The City in Black Kinship: A comparison of Rural Past and Urban Present," in Michael P. Smith, ed., Power, Community and the City: Comparative Urban and Community Research (1988), 108-138.

Fuller, Bruce, Susan D. Holloway, Marylee Rambaud and Costanza Eggers-Pierola, "How do Mothers Chose Child Care? Alternative Cultural Models in Poor Neighborhoods," Sociology of Education 69, 2 (1996), 83-105.

Gilkes, Cheryl Townsend, "A Case Study: Race-Ethnicity, Class and African American Women: Exploring the Community Connection," in Sue Rosenberg Zalk and Janice Gordon-Kelter, eds., Revolutions in Knowledge: Feminism in the Social Sciences (Boulder, CO: Westview Press, 1992), 63-78.

Greenbaum, Susan D., "The Preservation of Strawberry Hill: Continuity and Adaptation in an Urban Ethnic Neighborhood," Ethnic Groups 6, 4 (1985), 275-292.

Greenhalgh, Susan, "De-orientalizing the Chinese Family Firm," American Ethnologist 21, 4 (1994), 746-76.

Guarnaccia, Peter J. and Pilar Parra, "Ethnicity, Social Status, and Families: Experiences of Caring for a Mentally III Family Member," Community Mental Health Journal 32, 3 (1996), 243-59.

Guest, Avery and Keith Stamm, "Paths of Community Integration," Sociological Quarterly 34, 4 (1993), 581-595.

Hutchinson, Janis Faye, Nestor Rodriguez and Jacqueline Hagan, "Community Life: African Americans in Multiethnic Residential Areas," Journal of Black Studies 27, 2 (1996), 201-24.

Inglot, Tomasz, "Ethnic Political Power in a Machine City: Chicago's Poles at Rainbow's End," Urban Affairs Quarterly 28, 4 (1993), 526-544.

John, Daphne, Beth Anne Shelton and Kristen Luschen, "Race, Ethnicity, Gender and Perceptions of Fairness," Journal of Family Issues 16, 3 (1995), 357-80. 
Johnson, James H., Jr. and Melvin L. Oliver, "Interethnic Minority Conflicts in Urban America," Urban Geography 10, 5 (1989), 449-63.

Keith, Verna M., "Skin Tone and Stratification in the Black Community," American Journal of Sociology 97, 3 (1991), 760-79.

Kellogg, Susan, "Exploring Diversity in Middle-Class Families:The Symbolism of American Ethnic Identity," Social Science History 14,1 (1990), 27-42.

Kenzer, Robert C., "Family, Kinship, and Neighborhood in an Antebellum Southern Community, " in William J. Cooper, Michael F. Holt, John McCandell and David Herbert Donald, eds., A Master's Due (Baton Rouge: Louisiana State University Press, 1985), 112-137.

Klinger, Hannah, "Family, Kinship, and Ethnicity," in Walter P. Zenner, ed., Persistence and Flexibility: Anthropological Perspectives on the American Jewish Experience (Albany: State University of New York Press, 1988), 165-182.

Knight, George P., Martha E. Bernal, Camille A. Garza, Marya K. Cota and Katheryn A. Ocampo, "Family Socialization and the Ethnic Identity of Mexican-American Children," Journal of Cross-Cultural Psychology 24, 1 (1993), 99-115.

Knight, George P., Marya K. Cota and Martha E. Bernal, "The Socialization of Cooperative, Competition, and Individualistic Preferences Among Mexican American Children: The Mediating Role of Ethnic Identity," Hispanic Journal of Behavioral Sciences 15, 3 (1993), 291-310.

Lamborn, Susie D., Sanford M. Dornbusch and Laurence Steinburg, "Ethnicity and Community Context as Moderators of the Relations Between Family Decision Making and Adolescent Adjustment," Child Development 67, 2 (1996), 283-302.

Lazzari, Marceline M., Holly R. Ford and Kelly J. Haughey, "Making a Difference: Women of Action in the Community," Social Work 41, 2 (1996), 197-206.

Lee, Dong Ok, "Koreatown and Korean Small Firms in Los Angeles: Locating in the Ethnic Neighborhoods," Professional Geographer 47, 2 (1995), 184-96.

Lee, Dong Ok, "Commodifications of Ethnicity: The Sociospatial Reproduction of Immigrant Entrepreneurs," Urban Affairs Quarterly 28, 2 (1992), 258-276. 
Ethnic Studies Review, Vol. 19, No. 1

Leslie, Leigh A., "The Evolving Treatment of Gender, Ethnicity, and Sexual Orientations in Marital and Family Therapy," Family Relations 44, 4 (1995), 359-68.

Lin, Jan, "Ethnic Places, Postmodernism, and Urban Change in Houston," Sociological Quarterly 36, 4 (1995), 629-48.

Lipsitz, George, "The Meaning of Memory: Family, Class and Ethnicity in Early Television Programs," in Lynn Spigel and Denise Mann, eds., Private Screenings: Television and the Female Consumer (Minneapolis, MN: University of Minnesota Press, 1992), 71-110.

Marjoribanks, Kevin, "Cross-cultural Comparisons of Family Environments of Anglo-, Greek-, and Italian-Australians," Psychological Reports 74, 1 (1994), 49-51.

Molloy, Maureen, "Imagining (the) Difference: Gender, Ethnicity, and Metaphors of Nation," Feminist Review 51 (Autumn 1995), 94-103.

Naples, Nancy A., "Contradictions in Agrarian Ideology: Restructuring Gender, Race-Ethnicity, and Class," Rural Sociology 59, 1 (1994), 110136.

Oakes, Karen, "We Planted, Tended and Harvested Our Corn: Gender, Ethnicity, and Transculturation in 'A Narrative of the Life of Mrs. Mary Jemison'," Women and Language 18, 1 (1995), 45-51.

Parot, Joseph J., "Sources of Community Conflict in Chicago Polonia: Comparative Analysis a Historiographical Appraisal," Ethnicity 7, 4 (1980), 333-348.

Pessar, Patricia R., "Sweatshop Workers and Domestic Ideologies: Dominican Women in New York's Apparel Industry," International Journal of Urban and Regional Research 18, 1 (1994), 127-143.

Ruggles, Steven, "The Origins of African-American Family Structure," American Sociological Review 59, 1 (1994), 136-51.

Rumbaut, Ruben G., "The Crucible Within: Ethnic Identity, Self-Esteem, and Segmented Assimilation Among Children of Immigrants," International Migration Review 28, 4 (1994), 748-95.

Sandefur, Gary D. and Arthur Sakamoto, "American Indian Household Structure and Income," Demography 25, 1 (1988), 71-80. 
Sanderson, Bettie and Lawrence A. Kurdek, "Race and Gender as Moderator Variables in Predicting Relationship Satisfaction and Relationship Commitment in a Sample of Dating Heterosexual Couples," Family Relations 42, 3 (1993), 263-68.

Scourby, Alice, "The Interweave of Gender and Ethnicity," in Peter Kivisto, ed., The Ethnic Enigma (Philadelphia:The Balch Institute Press, 1989), 114-133.

Segura, Denise A. and Jennifer L. Pierce, "Chicana/o Family Structure and Gender Personality: Chodorow, Familism, and Psychoanalytic Sociology Revisited," Signs 19, 1 (1993), 62-92.

Shweder, Richard A., "'Why Do Men Barbecue?' and Other Postmodern Ironies of Growing Up in the Decade of Ethnicity," Daedalus 122, 1 (1993), 279-309.

Sjoberg, Gideon, Norma Williams, Elizabeth Gill, and Kelly F. Himmel, "Family Life and Racial and Ethnic Diversity: An Assessment of Communitarianism, Liberalism, and Conservatism," Journal of Family Issues 16, 3 (1995), 246-75.

Smith, Janet Farrell, "Analyzing Conflict in the Transracial Adoption Debate: Three Conflicts Involving Community," Hypatia 11, 2 (1996), 1-34.

Smith, Michael P., Bernadette Tarallo and George Kegiwada, "Colouring California: New Asian Immigrant Households, Social Networks and the Local State," International Journal of Urban and Regional Research 15, 2 (1991), 250-68.

Snipp, C. Mathew, "Understanding Race and Ethnicity in Rural America," Rural Sociology 61, 1 (1996), 125-43.

Song, Arthur, "The South African Chinese Family," Journal of Comparative Family Studies 24, 3 (1993), 353-66.

Song, Miri, "Between 'the Front' and 'the Back': Chinese Women's Work in Family Business," Women's Studies International Forum 18, 3 (1995), 285-99.

South, Scott J., "Racial and Ethnic Differences in the Desire to Marry," Journal of Marriage and the Family 55, 2 (1993), 357-71.

Starrels, Marjorie E., Sally Bould, and Leon J. Nicholas, "The Feminization of Poverty in the United States: Gender, Race, Ethnicity, and Family Factors," Journal of Family Issues 15, 4 (1994), 590-609. 
Ethnic Studies Review, Vol. 19, No. 1

Stoller, Eleanor Palo, "Sauna, Sisu and Sibelius: Ethnic Identity Among Finnish Americans," Sociological Quarterly 37, 1 (1996), 145-175.

Strobel, Lenny Mendoza, "'Born-Again Filipino': Filipino American Identity and Asian Panethnicity," Amerasia Journal 22, 2 (1996), 31-54.

Strom, Robert, Pat Collinsworth, and Shirley Strom, "Strengths and Needs of Black Grandparents," International Journal of Aging and Human Development 36, 4 (1993), 255-69.

Swartz, Marc J., "Politics, Ethnicity, and Social Structures: The Decline of an Urban Community During the Twentieth Century," Ethnology 35, 4 (1996), 233-49.

Taylor, Charles W., "Race, Ethnicity and the Struggle for an Inclusive Church and Society," in Pamela D. Couture and Rodney J. Hunter, eds., Pastoral Care and Social Conflict (Nashville, TN: Abingdon Press, 1995), 152-166.

Tirrito, Terry and Ilene Nathanson, "Ethnic Differences in Caregiving: Adult Daughters and Elderly Mothers," Affilia Journal of Women and Social Work 9, 1 (1994), 71-85.

Toungara, Jeanne Maddox, "Inventing the African Family: Gender and Family Law Reform in Cote D' Ivoire," Journal of Social History 28, 1 (1994), 37-52.

Valenzuela, Angela and Sanford M. Dornbusch, "Familism and Social Capital in the Academic Achievement of Mexican Origin and Anglo Adolescents," Social Science Quarterly 75, 1 (1994), 18-37.

Van Zile, Judy, "Non-Polynesian Dance in Hawaii: Issues of Identity in a Multicultural Community," Dance Research Journal 28, 1 (1996), 28-51.

Vittachi, Nury, "Relative Advantages: Mixed-Race Adoptions Can Be Tragicomedies with Happy Endings," Far Eastern Economic Review 157, 46 (1994), 60-2.

Weber, Linda R., Andrew Miracle and Tom Skehan, "Family Bonding and Delinquency: Racial and Ethnic Influences Among U.S. Youth," Human Organization 54, 4 (1995), 363-73.

Williams, Norma, Kelly F. Himmel, Andree F. Sjoberg and Diana J. Torrez, "The Assimilation Model, Family Life and Race and Ethnicity in the United States: The Case of Minority Welfare Mothers," Journal of Family Issues 16, 3 (1995), 380-406. 
Zinn, Maxine Baca, "Family, Race, and Poverty in the Eighties," Signs: Journal of Women in Culture and Society 14, 4 (1989), 856-74.

Zhou, Min and Carl L. Bankston III, "Social Capital and the Adaptation of the Second Generation: The Case of Vietnamese Youth in New Orleans," International Migration Review 28, 4 (1994), 821-46.

Zimmerman, Marc A., Jesus Ramirez-Valles, Kathleen M. Washienko, Benjamin Walter and Sandra Dryer, "The Development of a Measure of Enculturation for Native American Youth," American Journal of Community Psychology 24, 2 (1996), 295-311. 